\title{
Essential nutrient requirements of the elderly
}

\author{
This article was published in the following Dove Press journal: \\ Nutrition and Dietary Supplements \\ 12 June 2014 \\ Number of times this article has been viewed
}

\section{Robert Skully \\ Department of Family Medicine, Grant Medical Center, OhioHealth, Columbus, $\mathrm{OH}$, USA}

\begin{abstract}
Government-sponsored medical organizations in developed countries have established guidelines for daily nutritional requirements. For most nutrients there is general agreement surrounding these requirements, which are based on exhaustive scientific literature review. Differences in these recommendations exist because of genetic and environmental factors that result in differences in disease susceptibility, but also due to incomplete understanding of the roles of nutrients in disease prevention. This review briefly summarizes nutrient recommendations for older adults such as where those recommendations differ from those of younger adults; and includes areas of developing understanding such as the possible role of thiamine deficiency in patients with congestive heart failure, the need for some older adults to ingest absorbable forms of vitamin B12, the high prevalence of vitamin D deficiency, the potential role of vitamin $\mathrm{K}$ in bone health, the need for higher levels of protein intake in order to stimulate muscle protein synthesis as one ages, the role of calcium in osteoporosis, and the possible need for zinc supplementation in hospitalized patients.
\end{abstract}

Keywords: vitamins, nutritional requirements, energy expenditure, energy consumption

\section{Introduction}

Energy expenditure decreases with advancing age at a rate of about $150 \mathrm{kcal}$ per decade, ${ }^{1}$ and is accompanied by a decrease in energy consumption. Other than a decrease in caloric needs, there is no evidence that older individuals have lower nutrient needs, and in some cases nutritional requirements increase. Meeting these requirements may require consumption of more nutrient dense foods. Chronic illness, loss of appetite, and inability to access food often present further challenges to meeting the nutritional needs of the older adults.

A number of agencies have established guidelines for nutritional requirements. The estimated average requirement (EAR), the amount at which half of the group will require less, and the other half more, is a relatively universal term. The recommended daily allowance (RDA) is set two standard deviations above the EAR, so that it meets the nutritional requirements of $97 \%$ to $98 \%$ of the population and can be regarded as a goal. ${ }^{2}$ The RDA (as it is known in Canada, the United States, and Japan) is known as the RDI (recommended daily intake) in Australia and New Zealand; ${ }^{3}$ and RNI (reference nutrient intake) in the United Kingdom. ${ }^{4}$

\section{Vitamins}

There is general agreement on recommended nutrient requirements between medical organizations. Most clinically overt deficiencies are uncommon in industrialized 
countries. Those at risk for micronutrient deficiency are also at risk for overall nutritional deficiency, and so micronutrient deficiencies may present concomitantly, in a nonspecific manner, and be difficult to diagnose. Readily available laboratory testing only exists for folate, vitamin B12, and vitamin D.

Requirements for niacin, vitamin $\mathrm{C}$, biotin and pantothenic acid do not appreciably change with advancing age. These, along with all elderly nutritional requirements have been extensively reviewed recently. ${ }^{5}$

\section{Vitamin A}

The RDA for vitamin A is the same for older and younger adults. Older adults may absorb supplemental vitamin A more efficiently than younger adults ( $<60$ years), even the elderly with low vitamin A intake (below current recommendations) have normal vitamin A levels. The RDA for vitamin A is the same for older and younger adults, 900 and $700 \mathrm{mcg}$ retinol activity equivalents (RAE) for men and women, respectively. Although average intakes in the U.S. are below these recommendations, vitamin A deficiency is rare, ${ }^{6}$ and concerns about hypervitaminosis may may outweigh those of deficiency. ${ }^{7}$ Epidemiologic data show that populations with high levels of vitamin A intake are at increased risk for osteoporotic fractures, ${ }^{8}$ although possibly only in those who are deficient in vitamin D. ${ }^{9}$ The tolerable upper limit intake (UL) for vitamin A is 3,000 mcg per day.

\section{Thiamine (vitamin BI)}

Thiamine requirements do not change with age. Prior to thiamine fortification of grain products, low levels were seen commonly in older people. For example, $43 \%$ of 224 elderly people had thiamine levels below the fifth percentile of younger people in a New Zealand study, and lower levels correlated with age rather than comorbidities. ${ }^{10}$ Malabsorption of thiamine is seen in individuals who consume significant amounts of alcohol. In people with a history of alcohol abuse vitamin supplements, even in countries where grain products are fortified with thiamine, those patients with a history of alcohol abuse may need vitamin supplements to bring thiamine levels closer to those who are non-alcohol dependent. ${ }^{11}$

Congestive heart failure (CHF) is common in elderly patients, and is often accompanied by inadequate nutritional intake. As most CHF patients will be treated with loop diuretics, the hyper excretion of thiamine caused by loop diuretics places these patients at particular risk for thiamine deficiency. ${ }^{12}$ The prevalence of thiamine deficiency in $\mathrm{CHF}$ has been stated to be from $21 \%$ to $98 \% .{ }^{13}$ Several small
RCTs involving less than 50 patients have demonstrated improvement in cardiac parameters in patients who received thiamine supplements. ${ }^{13}$

\section{Riboflavin}

Riboflavin functions as a coenzyme in numerous redox reactions and in energy production. Daily requirements $(1.3 \mathrm{mg}$ in men, $1.1 \mathrm{mg}$ in women) do not diminish with age even though the elderly have lower energy expenditure. ${ }^{14}$

In Australia and New Zealand the recommended intake for riboflavin for patients over the age of 70 years of age is slightly higher (1.6 mg for men, $1.3 \mathrm{mg}$ for women), based on biochemical evidence of deficiency in $12 \%$ of noninstitutionalized elderly in a study conducted in the United Kingdom. ${ }^{15}$

\section{Vitamin B6}

There is no defined vitamin B6 deficiency disease, however, vitamin B6 is a cofactor in many enzymatic reactions, and its deficiency may have wide ranging effects and present with non-specific clinical manifestations. Experimentally, vitamin B6 deficiency impairs interleukin 2 production and depresses the response of lymphocytes to mitogen stimulation. ${ }^{16}$ Vitamin B6 deficiency variably correlates with various cancers, cardiovascular disease and cognitive decline, and several studies show a high prevalence of vitamin B6 deficiency in the elderly. ${ }^{17}$

Most daily recommendations for vitamin B6 for adults range from 1.2 to $1.4 \mathrm{mg}$, although recommendations are higher (1.7 mg for men, and $1.5 \mathrm{mg}$ for women) for adults over the age of 50 years in the United States, Canada, Australia, and New Zealand, due to evidence that $1.90 \mathrm{mg}$ per day was needed to normalize biochemical evidence of deficiency in twelve patients over the age of 60 years. ${ }^{18}$ The levels of plasma pyridoxal 5'-phosphate (PLP), the active form of vitamin B6, are probably the best indicator of vitamin B6 status. While setting target levels of PLP at $20 \mathrm{nmol} / \mathrm{L}$ may overestimate B6 requirements, this level provides a safety margin to protect against symptoms of deficiency, and so is considered optimal. ${ }^{14}$ National Health and Nutrition Examination Survey (NHANES) 2003 to 2004 data show that even at intakes of 2.0 to $2.9 \mathrm{mg}$ per day, $14 \%$ of those over the age of 65 years in the United States had levels of PLP $<20$ $\mathrm{nmol} / \mathrm{L} .{ }^{19}$ The UL for vitamin B6 is $100 \mathrm{mg}$ per day.

\section{Vitamin BI2}

Naturally occurring vitamin B12 is only found in foods of animal origin, such as meat, eggs, and dairy products. The 
RDA for adults living in Australia, New Zealand, Canada, and the United States, for vitamin B12 is $2.4 \mathrm{mcg}$, with slightly lower recommended intakes in other industrialized nations. Median dietary intakes in these countries exceed the RDA, and about $5 \%$ of older patients are deficient. ${ }^{20}$ When deficiency does occur, it is usually due to malabsorption rather than inadequate intake. Often the elderly will have an age-associated decrease in parietal cell activity with an attendant loss of secretion of gastric acid needed to cleave vitamin B12 from the proteins to which it is bound. When this occurs, intrinsic factor is unable to bind to vitamin B12 and malabsorption ensues. Elderly patients with vitamin B12 malabsorption will maintain the ability to absorb the crystalline vitamin B12 found in supplements and added to fortified foods, subsequently, Health Canada and the Institute of Medicine (IOM) both recommend that patients over the age of 50 years include vitamin B12-fortified foods in their diet, or take vitamin B12 supplements. ${ }^{6,21}$

\section{Adequate cobalamin status}

Serum B12 levels are easily measured and correlate with deficiency. Vitamin B12 deficiency will result in accumulation of homocysteine and methylmalonic acid, the latter of which is specific to vitamin B12 deficiency, subsequently, elevated methylmalonic acid levels can be used to diagnose vitamin B12 deficiency in patients with borderline low vitamin B12 levels, which may be seen in over $20 \%$ of patients over the age of $60 .{ }^{20}$

\section{Deficiency}

Vitamin B12 deficiency can result in a wide array of neurologic manifestations, although most patients with low vitamin B12 levels are asymptomatic. Patients may present with vague cognitive or psychiatric symptoms, and with the absence of the classic hematologic findings like anemia or macrocytosis, may be difficult to diagnose. ${ }^{22}$ Low vitamin B12 levels are a risk factor for cognitive decline, ${ }^{23}$ but treating patients with borderline low levels does not improve cognitive function. ${ }^{24}$

\section{Approach to the patient}

No medical organizations recommend routine screening of patients for vitamin B12 deficiency, although, given the high prevalence of low vitamin B12 levels, along with subtle manifestations of deficiency, clinicians should be alert to the possibility of vitamin B12 deficiency. Elderly patients should consume crystalline B12, either in the form of supplements or fortified foods, and for those who do not, particularly those with risk factors for malabsorption, such as prior gastric surgery, history of taking H2-blockers, proton pump inhibitors, or metformin, there should be a low threshold for laboratory investigation of vitamin B12 levels. Daily supplement intake as high as 10,000 times the RDA (30 mg) has been shown to be safe. ${ }^{25}$

\section{Folate}

There is no evidence that folate requirements change with advancing age. The RDA for folate in the United States, Canada, New Zealand and Australia for men and women is $400 \mathrm{mcg}$; $240 \mathrm{mcg}$ in Japan, and $200 \mathrm{mcg}$ in the United Kingdom. ${ }^{2,4,6,21}$ In order to decrease the number of children born with neural tube defects, many governments mandate folic acid fortification of grain products. In the United States, following folic acid fortification in 1998, mean folate concentrations rose from 4.6 to $10.0 \mathrm{ng} / \mathrm{mL}$, and the prevalence of low folate concentrations decreased from $22 \%$ to $1.7 \%$ in adults. ${ }^{26}$ Folate levels can readily be ascertained through available blood tests.

\section{Vitamin D}

The effect of ultraviolet (UV) light on 7-dehydrocholesterol found in the dermis and epidermis initiates a reaction which results in the formation of vitamin D (cholecalciferol, D3), a pro-hormone, which is converted to the active 1,25-dihydroxycholecalciferol. ${ }^{27}$ Because of lifestyle factors which result in low levels of UV exposure, vitamin D3 deficiency has become common, and for many people dietary consumption is now the primary means of vitamin D3 acquisition, particularly for older persons in institutional settings. ${ }^{27}$ As vitamin D3 is not naturally found in many foods, those foods supplemented with vitamin D3 (milk products, fortified cereals) are an important source. ${ }^{27}$ Oral supplementation has become routine, particularly for institutionalized elderly people. ${ }^{27}$

Table I Recommended adult vitamin D intake

\begin{tabular}{lll}
\hline Country & $\begin{array}{l}\text { Age } \\
\text { (years) }\end{array}$ & $\begin{array}{l}\text { Intake } \\
(\text { mcg per day) }\end{array}$ \\
\hline Australia/ & $51-70$ & 10 \\
New Zealand & & 15 \\
Canada $^{21}$ & $>70$ & 15 \\
& $51-70$ & 20 \\
Great Britain $^{29}$ & $>70$ & 10 \\
Japan $^{30}$ & $>65$ & $5.5^{* *}$ \\
United States $^{6}$ & $50-69$ & 15 \\
& $50-70$ & 20 \\
\hline
\end{tabular}

Notes: *Adequate intake, No RDA exists; ** I mcg $=40 \mathrm{IU}$.

Abbreviation: RDA, recommended daily allowance. 


\section{Vitamin $D$ requirements}

Vitamin D requirements are based on those intakes needed to maintain serum levels. Vitamin D is hydroxylated in the liver to 25-hydroxy-vitamin D [25(OH)D3], the levels of which correlate with vitamin $\mathrm{D}$ status. The definition of vitamin D sufficiency, a serum level of $75 \mathrm{nmol} / \mathrm{L}$ (30 ng/ $\mathrm{mL}$ ), is based on levels of parathyroid hormone and biological evidence of bone health. Desired vitamin D levels for other health outcomes, such as cancer and cardiovascular disease prevention, are unknown, however there is as yet no hard evidence that higher levels are beneficial. Also, the implications of low levels may be different for different ethnic groups. For example, low levels of 25(OH)D3, commonly seen in black Americans may reflect genetic polymorphisms affecting levels of vitamin $\mathrm{D}$ binding protein instead of true deficiency. ${ }^{31}$ Because older skin loses some ability to manufacture vitamin $\mathrm{D}$, and because the elderly are indoors more often, the elderly are at higher risk for vitamin D deficiency. Recommendations for vitamin D intake vary, in part due to variation in UV light available at different latitudes, but also based on differing conclusions reached from available data, and are listed in Table 1.

Both Health Canada and the IOM note that the primary source for vitamin $\mathrm{D}$ is fortified foods, and not sun exposure. In addition to obtaining vitamin D through food sources, Health Canada recommends that all adults over the age of 50 years consume a $400 \mathrm{IU}(10 \mathrm{mcg})$ supplement each day. ${ }^{31}$

\section{Current intakes}

In the United States, because it is more common for women to take vitamin D3 supplements in conjunction with calcium supplements, intakes are higher in women than men. ${ }^{27}$ For females aged 51 to 70 years, median vitamin D3 intake was $308 \mathrm{IU}$ daily, and for women over the age of 70 years, $356 \mathrm{IU}$ (160 IU from food, 196 IU from supplements). ${ }^{27}$ The ninetyfith percentile for vitamin D intake was $586 \mathrm{IU}$ per day for men, and $940 \mathrm{IU}$ per day for women, well below the UL of 4,000 IU per day. Under optimal conditions the human body can manufacture up to $10,000 \mathrm{IU}$ a day, ${ }^{33}$ and in one balance study conducted over two years, vitamin-replete middle-aged men in Nebraska were estimated to utilize approximately 4,000 IU vitamin D3 daily. ${ }^{34}$

\section{Fall and fracture prevention}

A meta-analysis of ten trials conducted in 2010 showed a $14 \%$ reduction in fall risk, with community dwellers over the age of 80 years, and persons taking at least $800 \mathrm{IU}$ ( $20 \mathrm{mcg}$ ) daily benefitting the most. Falls were reduced by $14 \%{ }^{35}$
There is consensus that vitamin D supplements decrease fracture risk in the elderly. A 2005 meta-analysis concluded that the ability of vitamin D to prevent non-vertebral fractures is dose-dependent, and that patients prescribed at least 700 to $800 \mathrm{IU}$ ( 17.5 to $20 \mathrm{mcg}$ ) vitamin D daily had a $26 \%$ decrease in hip fractures, and a $23 \%$ decrease in nonvertebral fractures, while $10 \mathrm{mcg}$ daily did not improve outcomes. ${ }^{36}$ Two subsequent meta-analyses by the same authors involving over 40,000 patients showed similar findings. ${ }^{37,38}$

\section{Other health outcomes}

Observation data suggest vitamin $\mathrm{D}$ insufficiency has a role in many adverse health outcomes, including cancer, and heart disease, ${ }^{39,40}$ however there are no randomized controlled trials (RCTs) demonstrating health benefits other than fall or fracture prevention as of yet.

\section{Summary and recommendations}

Vitamin D deficiency (serum levels of 25[OH]D $<50 \mathrm{nmol} / \mathrm{L}$ [20 ng/mL]) is common among elderly patients and is associated with adverse consequences. Irrespective of serum levels, elderly patients who are at risk of falling who take vitamin D3 supplements at doses of $800 \mathrm{IU}(20 \mathrm{mcg})$ daily have a decreased risk of falls and fractures. Other health benefits have not been supported by RCTs yet. Vitamin D intake of up to $4,000 \mathrm{IU}$ ( $100 \mathrm{mcg}$ ) daily is safe, and serum levels of 25(OH)D3 can be used to guide clinical decision making.

Because of the high prevalence of vitamin D deficiency in elderly adults, many clinicians consider either universal supplementation or universal screening for vitamin D deficiency. Both strategies were considered cost effective in a mathematical model of elderly patients in the United States. Screening for vitamin D deficiency was considered to be more cost effective (rather than empiric supplementation with $25 \mathrm{mcg}$ daily) in those over the age of 80 years, in whom $25 \mathrm{mcg}$ daily may be inadequate to normalize serum levels. ${ }^{41}$

\section{Vitamin E}

The RDI of vitamin $\mathrm{E}$ is $15 \mathrm{mg}$ for all adults, and most adults have normal levels. ${ }^{42,43}$ Because of its role as an antioxidant, vitamin $\mathrm{E}$ has been studied in degenerative diseases. While diets which are high in vitamin $\mathrm{E}$ are associated with lower mortality from coronary artery disease (CAD),${ }^{44}$ RCTs have not demonstrated that vitamin $\mathrm{E}$ supplements lower the risk of CAD. ${ }^{45,46}$ Similarly, while dietary vitamin E consumption is associated with lower rates of cognitive decline, ${ }^{47}$ high dose supplements (2,000 IU per day) have not been shown, 
in patients with mild cognitive impairment who are at high risk for developing Alzheimer's disease, to decrease the risk for such progression..$^{48}$ In contrast, a recent RCT showed high doses of vitamin E (2000 IU per day) to mildly slow functional decline in patients already diagnosed with mild to moderate Alzheimer disease over one year. ${ }^{49}$

\section{Vitamin K}

Vitamin $\mathrm{K}$ is found in green leafy vegetables, and its intake varies widely. The RDA for vitamin $\mathrm{K}$ is approximately $1 \mathrm{mcg}$ per $\mathrm{kg}$ of body weight, $(90 \mathrm{mcg}$ and $70 \mathrm{mcg}$ respectively for adult men and women), and is based on the amount needed for normal functioning of the clotting cascade. It is uncertain whether this amount is sufficient for adequate synthesis of other vitamin K-dependent proteins. For example, osteocalcin is a protein produced by osteoblasts which has a role in bone mineralization, the activity of which is determined by its level of vitamin K-dependent carboxylation. Studies have correlated a higher fracture rate with under-carboxylated osteocalcin. Since vitamin K intakes reported for the general population do not ensure complete carboxylation of osteocalcin, vitamin $\mathrm{K}$ requirements for bone function may be higher than what is needed to maintain hemostasis..$^{50,51}$ Women in the lowest quintile of vitamin $\mathrm{K}$ intake ( $<109 \mathrm{mcg}$ per day) had a 1.43 relative risk of hip fractures compared with the other quintiles in the Nurses' Health Study, ${ }^{52}$ and in the Framingham Heart Study those in the highest quartile of intake (median $254 \mathrm{mcg}$ per day) had a 0.35 relative risk for hip fractures compared with those in the lowest quartile (median intake 56 mcg per day). ${ }^{53}$ However, if vitamin $\mathrm{K}$ intake is critical for bone health, then the use of warfarin, a vitamin $\mathrm{K}$ antagonist, might be expected to have a negative effect on bones. While findings have been inconsistent, warfarin does not appear to cause clinically significant bone loss or an increased risk of fractures, ${ }^{51,54}$ and the understanding of the role of vitamin $\mathrm{K}$ in skeletal health is still evolving.

\section{Water}

The daily water intake required for adults is about $30 \mathrm{~mL}$ per $\mathrm{kg}$, or about 1,500 to $2,500 \mathrm{~mL}$. The percentage of whole body water decreases modestly with age, hence, loss of fluid is more significant in the elderly. When confronted with dehydration, the elderly kidney, even in the absence of disease, loses some ability to conserve water because of a loss in concentrating ability, which is predicted by the formula: maximal urine osmolarity $=1,134 \mathrm{mOsm}$ per $\mathrm{kg}-(4 \mathrm{mOsm}$ per $\mathrm{kg} \times$ age). ${ }^{55}$ An 80-year-old kidney, for example, will only maximally concentrate to $800 \mathrm{mOsm}$ per L, and, given a daily required urinary osmolar output of $800 \mathrm{mOsm}$, will have an additional obligatory 250 to $300 \mathrm{~mL}$ daily fluid loss compared to a young kidney. Minimum water requirements are therefore modestly higher in the elderly.

\section{Protein}

According to nitrogen balance studies, healthy adults have an average minimum dietary protein requirement of $0.66 \mathrm{~g}$ per $\mathrm{kg}$ of ideal body weight, and a calculated RDA of $0.8 \mathrm{~g}$ per $\mathrm{kg}$. This recommendation is the same for both young and older adults. ${ }^{56,57}$ While appropriate for establishing the minimum amount of protein required for short term homeostasis, balance studies are not designed to determine optimal clinical outcomes, ${ }^{3}$ and a number of authors have suggested that the protein requirement for the elderly should be increased to 1.0 to $1.2 \mathrm{~g}$ per $\mathrm{kg}$ per day or higher, ${ }^{58,59}$ and recommendations for protein intake for adults over the age of 70 years in Australia and New Zealand have been raised to a level 25\% higher than those for younger adults. ${ }^{60}$ Observational data suggest improved health outcomes in the elderly who have higher protein intakes. The Health Aging and Body Composition (Health $\mathrm{ABC}$ ) study showed that in persons 70 to 79 years of age, over a three-year period, those in the highest quintile of protein intake lost $40 \%$ less lean body mass compared with those in the lowest quintile. ${ }^{61}$ Another longer term nitrogen balance study showed that patients consuming the RDA for protein over a 14-week period lost mid-thigh muscle mass, suggesting that muscle strength may be at risk for patients consuming the current recommended protein intake. ${ }^{62}$

Unfortunately, supplementing frail elderly patients with protein and calories does not reflexively improve clinical outcomes. A review of nutritional supplements in 62 trials involving over 10,000 patients showed modest improvements in weight and mortality, primarily in those who were malnourished, with most trials showing no benefit of routine supplementation. ${ }^{63}$

\section{Dietary protein to enhance anabolism}

While the precise mechanisms are not completely understood, there is an imbalance between the synthesis and breakdown of muscle protein that accompanies aging, and the resultant progressive muscle weakness will invariably result in some degree of functional decline. ${ }^{64}$ In part this may be because aging muscle is less sensitive to the stimulant effect that dietary protein has on protein synthesis, so that higher levels of protein intake are required in the elderly to stimulate muscle anabolism. Specific feeding strategies may enhance this stimulation. "Fast" proteins, such as whey, stimulate 
muscle protein synthesis ${ }^{65}$ more than "slow" proteins, such as casein. Essential amino acids, particularly leucine, bind to receptors which stimulate muscle protein synthesis; and adding leucine to protein supplements increased the rate of muscle protein synthesis in ten elderly men in an RCT. ${ }^{66}$ Because age is associated with decreased chewing efficiency, even changes in food consistency may play a role in protein balance by increasing the rate at which amino acids from dietary protein enter the circulation. Whole body protein balance was more positive after ingesting minced beef than beef steak in ten elderly men. ${ }^{67}$

\section{Potential negative impact of increasing dietary protein Osteoporosis}

Increasing dietary protein does result in a higher urinary calcium excretion, which, if due to calcium buffering acids generated from protein metabolism, could predispose to osteoporosis. However, higher protein intakes improve intestinal calcium absorption, and increase calcium retention, especially when calcium intake is low. ${ }^{68}$ Epidemiologic data also support improved skeletal health with higher protein intakes. ${ }^{69}$

\section{Kidney disease}

Higher protein intakes cause hyperfunctioning of the glomerular basement membrane which results in worsening proteinuria. Protein intake of $1.1 \mathrm{~g}$ per $\mathrm{kg}$ does not appear to reduce renal function in elderly patients with normal renal function..$^{70}$ For patients with kidney disease, the National Kidney Foundation has established guidelines for protein intake, and recommends 0.60 to $0.75 \mathrm{~g}$ per $\mathrm{kg}$ for patients with a creatinine clearance $<25 \mathrm{~mL}$ per minute. Patients on chronic dialysis require a higher amount of protein and should receive $1.2 \mathrm{~g}$ per kg daily. ${ }^{71}$

\section{Exercise}

Dietary protein is more effective at stimulating muscle anabolism when accompanied by resistance exercises. Meta-analysis suggests that in older (62 years \pm 6 years) patients both fat-free mass and strength gains from resistance exercises are augmented by protein supplementation, even in patients already consuming adequate amounts of protein. ${ }^{72}$ Protein supplements alone (15 g added to breakfast and lunch) did improve physical performance in an RCT of 65 frail elderly (average age 78) who were already consuming on average $65 \mathrm{~g}$ of protein per day. ${ }^{73}$ When prolonged resistance-type exercise training was added twice
Table 2 Recommended daily allowances (RDA) for calcium in representative countries

\begin{tabular}{lllll}
\hline Country & Sex & $\begin{array}{l}\text { Age, } \\
\text { years }\end{array}$ & $\begin{array}{l}\text { RDA for calcium } \\
\text { mg/day }\end{array}$ & Reference \\
\hline Australia/ & Male & $51-70$ & 1,000 & 28 \\
New Zealand & & $>70$ & 1,300 & \\
& Female & $51-70$ & 1,300 & \\
& & $>70$ & 1,300 & 2 \\
Canada/ & Male & $51-70$ & 1,000 & \\
United States & & $>70$ & 1,200 & \\
& Female & $51-70$ & 1,200 & 30 \\
Japan & & $>70$ & 1,200 & \\
& Male & $50-69$ & 700 & \\
& & $>70$ & 700 & 4 \\
United & Female & $50-69$ & 650 & \\
Kingdom & Male & $>50$ & 600 & 700 \\
\hline
\end{tabular}

weekly for 6 months, an increase in lean body mass was observed. ${ }^{73,74}$

\section{Calcium}

In the United States the lifetime incidence of fragility fractures approaches $40 \%$ in women and $10 \%$ in men. Since nearly $99 \%$ of the calcium content of the human body is contained in the skeleton, it makes sense that an adequate calcium intake should be an important part of the nutritional plan for most elderly, and almost $70 \%$ of postmenopausal women in the United States take calcium supplements. ${ }^{75}$

\section{Calcium recommendations}

A quarter of a century ago Kanis and Passmore argued against the use of calcium supplements, questioning the relevance of balance studies in defining an adequate calcium intake, and noting that low levels of calcium intake stimulate more efficient intestinal absorption. ${ }^{76}$ Since this intestinal adaptation may take months to occur, short term balance studies, they argued, may underestimate the efficiency of calcium absorption, and so overestimate calcium requirements. ${ }^{76}$ Despite being difficult to perform, balance studies continue to be an important component in calculating calcium requirements. ${ }^{27}$ Confounding variables include the variability of calcium absorption from different foods and supplements, the effects that other dietary factors such as protein and salt have on calcium absorption, and especially the presence or absence of vitamin D deficiency. ${ }^{27}$ The high prevalence of osteoporosis in the US alone argues for high calcium intakes, yet the ability of an increased calcium intake to overcome the effects of bone loss related to aging continues to be debated. ${ }^{21}$ Compared 
with younger adults, current United States recommendations for calcium intake are modestly higher for women and persons over the age of 70 years. For most people, achieving these levels will necessitate ingesting dietary supplements. Recommendations from other organizations are similar (Table 2). The RDA for calcium in Japan is lower than most other industrialized countries, and Japanese women consume less calcium than those in the United States, (400 mg versus $650 \mathrm{mg}$ ) yet have a lower rate of hip fractures. ${ }^{77}$

\section{Calcium and osteoporosis}

For over 20 years studies have pointed to modest increases in bone density in patients taking calcium supplements. An RCT of 301 healthy postmenopausal women in 1990 demonstrated that $500 \mathrm{mg}$ daily elemental calcium supplementation lessened bone loss over 2 years, but primarily in women who had a prior calcium intake of $<400 \mathrm{mg}$ per day. ${ }^{78}$ Postmenopausal women receiving higher doses (1,000 mg per day) of calcium supplements for 2 years had similar improvements in bone density, even when they had had higher calcium intakes prior to enrollment. ${ }^{79}$

Recent trials on fracture prevention have often included supplementing subjects with both calcium and vitamin D, which tends to obscure the individual role of calcium in fracture prevention. In a prospective cohort study of 61,433 Swedish women followed for up to 19 years, fracture rates were highest for those in the lowest quintile of calcium intake. In this group, fracture rates were similar for the other four quintiles, suggesting that in this population, calcium supplements may be indicated for those only at the lowest intake levels. ${ }^{80} \mathrm{~A}$ meta-analysis of RCTs involving 1,806 patients from 2002 concluded that calcium supplements have a small positive effect on bones, with a $2 \%$ increase in bone density, and that the risk of vertebral and non-vertebral fractures was decreased, but not to a statistically significant degree. ${ }^{81}$ A larger meta-analysis involving over 63,000 patients concluded that with regard to calcium, supplements did lower fracture rates, and that rates were most improved with supplement doses $>1,200 \mathrm{mg}$ per day, in patients with low vitamin D levels, in patients with a low baseline calcium intake ( $<700 \mathrm{mg}$ per day), and in patients over 70 years of age. ${ }^{82}$

\section{Other effects of calcium}

Calcium supplements may increase the risk for kidney stones. ${ }^{83}$ Recent evidence suggests a possible negative effect on coronary heart disease. An RCT involving 1,471 patients taking calcium or placebo for 5 years showed a significant increase in myocardial infarction in the treatment group, ${ }^{84}$ though no adverse cardiac events were seen from calcium and vitamin D supplementation in the Women's Health Initiative ${ }^{85}$ In over 60,000 women in the Swedish mammography cohort followed on an average for 19 years, those women with calcium intakes over $1,400 \mathrm{mg}$ daily had significantly higher all-cause mortality. ${ }^{86}$

\section{Iron}

Iron requirements for premenopausal women are more than twice that for men, but after the age of menopause those requirements decrease so that requirements are the same for both sexes. Iron deficiency in the elderly is more commonly the result of illness than inadequate intake.

\section{Zinc}

Recommended intakes for zinc are the same for older and younger adults. According to the IOM the RDA is 8 $\mathrm{mg}$ for women and $11 \mathrm{mg}$ for men. ${ }^{50}$ In the United States, where patients commonly take dietary supplements, $35 \%$ to $45 \%$ of elderly adults had inadequate dietary intakes, and even in those elderly consuming dietary supplements, $20 \%$ to $25 \%$ may not meet the RDA. ${ }^{87}$ Twenty frail homebound elderly in the United Kingdom were found to be in negative zinc balance with mean daily intakes of $6 \mathrm{mg}$ $(90 \mathrm{mmol})$. Zinc intakes correlated best with protein and energy intakes. ${ }^{88}$

Zinc is required in over 300 enzymatic reactions, so the consequences of zinc deficiency may be widespread; however, the diagnosis of zinc deficiency is difficult. Even abnormalities of taste, seen characteristically in zinc deficiency, may be a poor marker of zinc status. ${ }^{89}$ Zinc levels are not routinely ordered in clinical practice, and diagnosis is complicated by a lack of reliable laboratory markers. ${ }^{90}$

A decrease in T-cell medicated immunity is seen in both senescence and zinc deficiency. In 617 patients in Boston nursing homes who had low serum zinc concentrations $(<70 \mathrm{mcg} / \mathrm{dL})$ there was higher incidence of pneumonia, antibiotic use, and all-cause mortality ${ }^{91}$ Zinc supplementation, (zinc gluconate given as $45 \mathrm{mg}$ of elemental zinc daily) in 50 healthy older adults reduced the incidence of minor illnesses over 1 year, while lowering levels of inflammatory cytokines. ${ }^{92}$ Because of the role of zinc in the immune system, some suggest zinc supplementation for all hospitalized patients. ${ }^{93}$

\section{Conclusion}

Although through efficient absorption of calcium the body can maintain an adequate calcium balance at various intakes, most 
organizations place the optimal daily calcium intake at 1,000 to 1,200 mg. Calcium balance studies generally support this level of intake. Positive effects from increasing calcium intakes are more likely to be seen in those with low intakes. In the absence of significant dairy consumption ( $250 \mathrm{cc}$ milk contains about $300 \mathrm{mg}$ elemental calcium), to achieve these recommended intakes, most adults will need to ingest calcium supplements, the effects of which have recently been reviewed. ${ }^{94}$

There are significant differences in the recommended calcium intakes from different organizations, even when the populations are from similar ethnic origins (United Kingdom and Australia/New Zealand). United States Preventative Services Task Force recently made recommendations regarding calcium and vitamin D supplements for the prevention of falls and fractures, and recommended against using calcium supplements in doses $<1,000 \mathrm{mg}$ (and $<400 \mathrm{IU}$ vitamin D), while noting that there are insufficient data regarding calcium supplements in doses $>1,000 \mathrm{mg}$ per day and vitamin D >400 IU. ${ }^{95}$

\section{Disclosure}

The author reports no conflicts of interest in this work.

\section{References}

1. Roberts SB, Dallal GE. Energy requirements and aging. Public Health Nutr. 2005;8(7A):1028-1036.

2. United States Department of Agriculture [webpage on the internet]. National Agricultural Library. Available from: http://www.fnic. nal.usda.gov/dietary-guidance/dietary-reference-intakes/dri-table. Accessed March 7, 2014.

3. Nutrient Reference Values for Australia and New Zealand. Introduction [webpage on the internet]. Ministry of Health. Available from: http:// www.nrv.gov.au/Introduction.htm. Accessed March 7, 2014.

4. Nutrient requirements [webpage on the internet]. British Nutrition Foundation. Available from: http://www.nutrition.org.uk/nutritionscience/ nutrients/nutrient-requirements. Accessed March 7, 2014.

5. Chernoff R. Geriatric Nutrition: The Health Professional's Handbook. 4th ed. Massachusetts: Jones and Bartlett Learning; 2014.

6. Food and Nutrition Board, Institute of Medicine, National Academies. Dietary Reference Intakes (DRIs): Recommended Dietary Allowances and Adequate Intakes, Vitamins ion/edu/. Available from: activitities/ nutrition/summaryDRIs/-/media/files/activity\%20files/nutrition/DRIs/ ROA\%20and\%20AIs_vitamin\%20and\%20elements.pdf. Accessed March 10, 2014

7. Ballew C, Bowman BA, Russell RM, Sowel AL, Gillespie C. Serum retinyl esters are not associated with biochemical markers of liver dysfunction in adult participants in the third National Heath and Nutrition Examination Survey (NHANE III), 1988-1994. Am J Clin Nutr. 2001;73:934-940.

8. Chernoff R. Micronutrient requirements of older women. Am J Clin Nutr. 2005;81(5):1240S-1245S.

9. Caire-Juvera G, Ritenbaugh C, Wactawski-Wende J, Snetselaar LG, Chen Z. Vitamin A and retinol intakes and the risk of fractures among participants of the Women's Health Initiative Observational Study. Am J Clin Nutr. 2009;89:323-330.

10. Wilkinson TJ, Hange HC, George PM, Sainsbury R. Is thiamine deficiency in elderly people related to age or comorbidity? Age Ageing. 2000;29(2):111-116.
11. Rees E, Gowing LR. Supplementary thiamine is still important in alcohol dependence. Alcohol Alcohol. 2013;48(1):88-92.

12. Wooley JA. Characteristics of thiamin and its relevance to the management of heart failure. Nutr Clin Pract. 2008;23:487.

13. DiNicolantonio JJ, Niazi AK, Lavie CJ, O'Keefe JH, Ventura HO. Thiamine supplementation for the treatment of heart failure: a review of the literature. Congest Heart Fail. 2013;19(4):214-222.

14. Institute of Medicine. Dietary Reference Intakes for Thiamin, Riboflavin, Niacin, Vitamin B6, Folate, Vitamin B12, Pantothenic Acid, Biotin, and Choline. Washington, DC: The National Academies Press; 1998. Available at http://www.nap.edu/openbook.php?record_id=6015. Accessed March 7, 2014.

15. Nutrient Reference Values for Australia and New Zealand. Riboflavin [webpage on the internet]. Ministry of Health. Available from: http:// www.nrv.gov.au/nutrients/riboflavin.htm. Accessed March 7, 2014.

16. Meydani SN, Ribaya-Mercado JD, Russell RM, Sayhoun N, Morrow FD, Gershoff SN. Vitamin B-6 deficiency impairs interleukin 2 production and lymphocyte proliferation in elderly adults. Am J Clin Nutr. 1991;53(5):1275-1280.

17. Spinneker A, Sola R, Lemmen V, Castillo MJ, Pietrzik K, GonzalezGross M. Vitamin B6 status, deficiency and its consequences - an overview. Nutr Hosp. 2007;22(1):7-24.

18. Ribaya-Mercado JD, Russell RM, Sahyoun N, Morrow FD, Gershoff SN. Vitamin B6 requirements of elderly men and women. J Nutr. 1991;121(7):1062-1074.

19. Morris MS, Picciano MF, Jacques PF, Selhub J. Plasma pyridoxal 5 '-phosphate in the US population: the National Health and Nutrition Examination Survey, 2003-2004. Am J Clin Nutr. 2008;87(5):1446-1454.

20. Allen LH. How common is vitamin B-12 deficiency? Am J Clin Nutr. 2009;89(2):693S-696S.

21. Dietary Reference Intakes [webpage on the internet]. Health Canada. Available from: hc-sc.gc.ca/fn-an/nutrition/reference/table/ref_vitam_ tbl-eng.php. Accessed March 10, 2014.

22. Lindenbaum J, Healton E, Savage DG, et al. Neuropsychiatric disorders caused by cobalmin deficiency in the absence of anemia or macrocytosis. N Engl J Med. 1988;318(26):1720-1728.

23. Clarke R, Birks J, Nexo E, et al. Low vitamin B-12 status and risk of cognitive decline in older adults. Am J Clin Nutr. 2007;86(5): 1384-1391.

24. Eussen SJ, de Groot LC, Joosten LW, et al. Effect of oral vitamin B-12 with or without folic acid on cognitive function in older people with mild vitamin B-12 deficiency: a randomized, placebo-controlled trial. Am J Clin Nutr. 2006;84(2):361-370.

25. Marks J. The safety of the vitamins: an overview. Int J Vitam Nutr Res Suppl. 1989;30:12-20.

26. Jacques PF, Selhub J, Bostom AG, Wilson PW, Rosenberg IH. The effect of folic acid fortification on plasma folate and total homocysteine concentrations. N Eng J Med. 1999;340(19):1449-1454.

27. Institute of Medicine. Dietary Reference Intakes for Calcium and Vita$\min D$. Washington, DC: National Academies Press; 2011. Available at http://www.nap.edu/openbook.php?record_id=13050. Accessed March $10,2014$.

28. Nutrient Reference Values for Australia and New Zealand. Vitamin D [webpage on the internet]. Ministry of Health. Available from: http:// www.nrv.gov/Nutrients/vitamin\%20d.htm. Accessed March 10, 2014.

29. British Nutrition Foundation. Reference Nutrient intakes for Vitamins. Available from: http://www.nutrition.org.uk/attachments/053 Micronutrient\%20DRVs.pdf. Accessed March 10, 2014.

30. National Institute of Health and Nutrition, Department of Nutritional Epidemiology. Dietary Reference Intakes for Japanese 2010: The summary report from the Scientific Committee of "Dietary Reference Intakes for Japanese". Available from: http://www0.nih.go.jp/eiken/info/pdf/ dris2010en.pdf. Accessed March 10, 2014.

31. Powe CE, Evans MK, Wenger J, et al. Vitamin D-binding protein and vitamin D status of black and white Americans. $N$ Eng J Med. 2013;369(21):1991-2000. 
32. Vitamin D and Health. About Health Canada [webpage on the Internet]. Available from: http://www.healthycanadians.gc.ca/recall-alert-rappelavis/hc-sc/2007/13208a-eng.php. Accessed March 10, 2014.

33. Vieth R. Vitamin D supplementation, 25-hydroxyvitamin D concentrations, and safety. Am J Clin Nutr. 1999;69(5):842-856.

34. Heaney RP, Davies KM, Chen TC, Holick MF, Barger-Lux MJ. Human serum 25-hydroxycholecalciferol response to extended oral dosing with cholecalciferol. Am J Clin Nutr. 2003;77(1):204-210.

35. Kalyani RR, Stein B, Valiyil R, Manno R, Maynard JW, Crews DC. Vitamin D treatment for the prevention of falls in older adults: systemic review and meta-analysis. J Am Geriatr Soc. 2010;58(7):1299-1310.

36. Bischoff-Ferrari HA, Willett WC, Wong JB, Giovannucci E, Dietrich T, Dawson-Hughes B. Fracture prevention with vitamin D supplementation. JAMA. 2005;293(18):2257-2264.

37. Bischoff-Ferrari HA, Willett WC, Wong JB, et al. Prevention of nonvertebral fractures with oral Vitamin D and dose dependency. Arch Intern Med. 2009;169(6):551-561.

38. Bischoff-Ferrari HA, Willett WC, Orav EJ. A pooled analysis of vitamin D dose requirements for fracture prevention. $N$ Engl J Med. 2012;367(1):40-49.

39. Lee J, O'Keefe JH, Bell D, Hensrud DD, Holick MF. Vitamin D deficiency, an important, common, and easily treatable cardiovascular risk factor? J Am Coll Cardio. 2008;52(24):1949-1956.

40. Bischoff-Ferrari HA, Giovannucci E, Willitt WC, Dietrich T, DawsonHughes B. Estimation of optimal serum concentration of 25-hydroxyvitamin D for multiple health outcomes. Am J Clin Nutr. 2006;84(1):18-28.

41. Lee RH, Weber T, Colon-Emeric C. Comparison of cost-effectiveness of vitamin D screening with that of universal supplementation in preventing falls in community-dwelling older adults. J Am Geriatr Soc 2013;61(5):707-714.

42. Institute of Medicine. Dietary Reference Intakes for Vitamin C, Vitamin E, Selenium and Carotenoids. Washington, DC: Nationa Academies Press; 2000. Available at http://www.nap.edu/openbook php?record_id=9810. Accessed May 30, 2014.

43. Sutter PM. Vitamin nutriture in older adults. In: Chernoff R editor. Geriatric Nutrition, The Health Professional's Handbook. 4th ed. Burlington, MA: Jones and Bartlett; 2014

44. Knekt P, Reunanen A, Jarvinen R, Seppanen R, Heliovaara M, Aromaa A. Antioxidant vitamin intake and coronary mortality in a longitudinal population study. Am J Epidemiol. 1994;139(12):1180-1189.

45. Lonn E, Bosch J, Yusuf S, et al. Effects of long-term vitamin E supplementation on cardiovascular events and cancer: a randomized controlled trial. JAMA. 2005;293(11):1338-1347.

46. Sesso HD, Buring JE, Christen WG, et al. Vitamins E and C in the prevention of cardiovascular disease in men: the Physicians' Health Study II randomized controlled trial. JAMA. 2008;300(18):2123-2133.

47. Morris MC, Evand DA, Bienias JL, Tangney CC, Wilson RS. Vitamin E and cognitive decline in older persons. Arch Neurol. 2002; 59(7):1125-1132.

48. Petersen RC, Thomas RG, Grundman M, et al. Vitamin E and donepezil for the treatment of mild cognitive impairment. $N$ Engl J Med. 2005;352(23):2379-2388.

49. Dysken M, Sano M, Asthana S, et al. The effect of vitamin E and memantine on functional decline in Alzheimer disease. J Am Med Assoc. 311(1):33-44.

50. Institute of Medicine. Dietary Reference Intakes for Vitamin A, Vitamin K, Arsenic, Boron, Chromium, Copper, Iodine, Manganese, Molybdenum, Nickel, Silicon, Vanadium, and Zinc. Washington, DC: The National Academies Press; 2001. Available at http://www.nap.edu/openbook php?record_id=10026. Accessed March 10, 2014.

51. Booth SL. Roles for Vitamin K beyond coagulation. Ann Rev Nutr. 2009;29:89-110

52. Feskanich D, Weber P, Willett WC, Rockett H, Booth SL, Colditz GA. Vitamin $\mathrm{K}$ intake and hip fractures in women: a prospective study. Am J Clin Nutr. 1999;69(1):74-79.

53. Booth SL, Tucker KL, Hannan MT, et al. Dietary vitamin K intakes are associated with hip fracture but not with bone mineral density in elderly men and women. Am J Clin Nutr. 2000;71(5):1201-1208.
54. Woo C, Chang LL, Ewing SK, Bauer DC; Osteoporotic Fractures in Men Study Group. Single-point assessment of warfarin use and risk of osteoporosis in elderly men. J Am Geriatr Soc. 2008;56(7):1171-1176.

55. Lindeman RD, Van Buren HC, Raisz LG. Osmolar renal concentrating ability in healthy young men and hospitalized patients without renal disease. N Engl J Med. 1960;262:1306-1309.

56. Institute of Medicine. Dietary Reference Intakes for Energy, Carbohydrate, Fiber, Fat, Fatty Acids, Cholesterol, Protein, and Amino Acids (Macronutrients). Washington, DC: National Academies Press; 2005. Available at http://www.nap.edu/openbook.php?record_id=10490. Accessed March 10, 2014.

57. Campbell WW, Johnson CA, McCabe GP, Carnell NS. Dietary protein requirements of younger and older adults. Am J Clin Nutr. 2008;88(5):1322-1329.

58. Gaffney-Stomberg E, Insogna KL, Rodriguez NR, Kerstetter JE. Increasing dietary protein requirements in elderly people for optimal muscle and bone health. J Am Geriatr Soc. 2009;57(6):1073-1079.

59. Bauer J, Biolo G, Cederholm T, et al. Evidence-based recommendations for optimal dietary protein intake in older people: a position paper from the PROT-AGE Study Group. J Am Med Dire Assoc. 2013;14(8): $542-559$.

60. Nutrient Reference Values for Australia and New Zealand. Protein [webpage on the internet]. Ministry of Health. Available from: http:// www.nrv.gov.au/nutrients/protein.htm. Accessed March 10, 2014

61. Houston DK, Nicklas BJ, Ding J, et al. Dietary Protein intake is associated with lean mass change in older, community-dwelling adults: the Heath, Aging, and Body Composition (Health ABC) study. Am J Clin Nutr. 2008;87(1):150-155.

62. Campbell WW, Trappe TA, Wolfe RR, Evans WJ. The recommended dietary allowance for protein may not be adequate for older people to maintain skeletal muscle. J Gerontol A Biol Sci Med Sci. 2001;56(6): M373-M380.

63. Milne AC, Potter J, Vivanti A, Avenell A. Protein and energy supplementation in elderly people at risk for malnutrition. Cochrane Database Syst Rev. 2009;2:CD003788.

64. Evans WJ, Paolisso G, Abbatecola AM, Corsonello A, Bustacchini S, Strollo F, Lattanzio F. Frailty and muscle metabolism dysregulation in the elderly. Biogerontology. 2010;11(5):527-536.

65. Fujita S, Volpi E. Amino acids and muscle loss with aging. J Nutr. 2006;136(1):277S-280S.

66. Wall BT, Hamer HM, de Lange A, et al. Leucine co-ingestion improves post-prandial muscle protein accretion in elderly men. Clin Nutr. 2013;32(3):412-419.

67. Pennings B, Groen BB, van Dijk JW, et al. Minced beef is more rapidly digested and absorbed than beef steak, resulting in greater postprandial protein retention in older men. Am J Clin Nutr. 2013;98(1): $121-128$.

68. Hunt JR, Johnson LK, Fariba Roughead ZK. Dietary protein and calcium interact to influence calcium retention: a controlled feeding study. $\mathrm{Am}$ J Clin Nutr. 2009;89(5):1357-1365.

69. Hannan MT, Tucker KL, Dawson-Hughes B, Cupples LA, Felson DT, Kiel DP. Effect of dietary protein on bone loss in elderly men and women: the Framingham Osteoporosis Study. J Bone Miner Res. 2000;15(12):2504-2512.

70. Martin WF, Armstrong LE, Rodriguez NR. Dietary protein intake and renal function. Nutr Metab (Lond). 2005;2:25.

71. National Kidney Foundation. American Journal of Kidney Diseases. Available from: kidney.org/professionals/kdoqi/pdf/ KDOQI2000NutritionGL.pdf. Accessed March 10, 2014.

72. Cermak NM, Res PT, de Groot LC, Saris WH, van Loon LJ. Protein supplementation augments the adaptive response of skeletal muscle to resistance-type exercise training: a meta-analysis. Am J Clin Nutr. 2012;96(6):1454-1464.

73. Tieland M, van de Rest O, Dirks ML, et al. Protein supplementation improves physical performance in frail elderly people: a randomized, double-blind, placebo-controlled trial. J Am Med Dir Assoc. 2012;13(8):720-726. 
74. Tieland M, Dirks ML, van der Zwaluw N, et al. Protein supplementation increases muscle mass gain during prolonged resistance-type exercise training in frail elderly people: a randomized, doubleblind, placebo-controlled trail. J Am Med Dir Assoc. 2012;13(8): 713-719.

75. Baily RL, Dodd KW, Goldman JA, et al. Estimation of total usual calcium and vitamin D intakes in the United States. J Nutr. 2010;140(4): 817-822.

76. Kanis JA, Passmore R. Calcium supplementation of the diet-I, not justified by present evidence. BMJ. 1989;298:137-140.

77. Fujita T, Fukase M. Comparison of osteoporosis and calcium intake between Japan and the United States. Proc Soc Exp Biol Med. 1992;200(2):149-152.

78. Dawson-Hughes B, Dallal GE, Krall EA, Sadowski L, Sahyoun N, Tannenbaum S. A controlled trial of the effect of calcium supplementation on bone density in postmenopausal women. $N$ Engl J Med. 1990;323(13):878-883.

79. Reid IR, Ames RW, Evans MC, Gamble GD, Sharpe SJ. Effect of calcium supplementation on bone loss in postmenopausal women. $N$ Engl J Med. 1993;328(7):460-464.

80. Warensjo E, Byberg L, Melhus H, et al. Dietary calcium intake and risk of fracture and osteoporosis: prospective longitudinal cohort study. BMJ. 2011;342:d1473.

81. Shea B, Wells G, Cranney A, et al. Meta-analysis of calcium supplementation for prevention of postmenopausal osteoporosis. VII. Meta-analysis of calcium supplementation for the prevention of postmenopausal osteoporosis. Endocr Rev. 2002;23(4): $552-559$.

82. Tang BM, Eslick GD, Nowson C, Smith C, Bensoussan A. Use of calcium or calcium in combination with vitamin $\mathrm{D}$ supplementation to prevent fractures and bone loss in people aged 50 years and older: a meta-analysis. Lancet. 2007;370(9588):657-666.

83. Jackson RD, LaCroix AZ, Gass M, et al. Calcium plus vitamin D supplementation and the risk of fractures. N Engl J Med. 2006;354(7): 669-683.
84. Bolland MJ, Barber PA, Doughty RN, et al. Vascular events in healthy older women receiving calcium supplementation: randomised controlled trial. BMJ. 2008;336(7638):262-266.

85. Hsia J, Heiss G, Ren H, et al. Calcium/vitamin D supplementation and cardiovascular events. Circulation. 2007;115(7):846-854.

86. Michaelsson K, Melhus H, Warensjo Lemming E, Wolk A, Byberg L. Long term calcium intake and rates of all cause and cardiovascular mortality: community based prospective longitudinal cohort study. BMJ. 2013;346:f228.

87. Ervin RB, Kennedy-Stephenson J. Mineral intakes of elderly adult supplement and non-supplement users in the third national health and nutrition examination Survey. J Nutr. 2002;132(11):3422-2427.

88. Bunker VW, Hinks LJ, Stansfield MF, Lawson MS, Clayton BE. Metabolic balance studies for zinc and copper in housebound elderly people and the relationship between zinc balance and leukocyte zinc concentrations. Am J Clin Nutr. 1987;46(2):353-359.

89. Sandstead HH, Hendricksen LK, Greger JL, Prasad AD, Good RA. Zinc nutriture in the elderly in relation to taste acuity, immune response, and wound healing. Am J Clin Nutr. 1982;36(Suppl 5):1046-1059.

90. Hambridge M. Human zinc deficiency. J Nutr. 2000;130(Suppl 5S): 1344S-1349S.

91. Meydani SN, Barnett JB, Dallal GE, et al. Serum zinc and pneumonia in nursing home elderly. Am J Clin Nutr. 2007;86(4):1167-1173.

92. Prasad AS, Beck FW, Bao B, et al. Zinc supplementation decreases incidence of infections in the elderly: effect of zinc on generation of cytokines and oxidative stress. Am J Clin Nutr. 2007;85(3): 837-844.

93. Haasa H, Rink L. The immune system and the impact of zinc during aging. Immun Ageing. 2009;6:9

94. Bauer DC. Calcium supplements and fracture prevention. $N$ Engl $J$ Med. 2013;369(16):1537-1543.

95. US Preventive Sersvices Task Force. Vitamin D and Calcium Supplementation to Prevent Fractures in Adults [webpage on the Internet]. Available from: http://www.uspreventativeservicestaskforce.org/ uspstf12/vitamind/finalrecvitd.htm. Accessed March 10, 2014.
Nutrition and Dietary Supplements

\section{Publish your work in this journal}

Nutrition and Dietary Supplements is an international, peer-reviewed, open access journal focusing on research into nutritional requirements in health and disease, impact on metabolism and the identification and optimal use of dietary strategies and supplements necessary for normal growth and development. The journal welcomes papers covering

\section{Dovepress}

original research, basic science, clinical \& epidemiological studies, reviews and evaluations, guidelines, expert opinion and commentary, case reports and extended reports. The manuscript management system is completely online and includes a very quick and fair peer-review system, which is all easy to use. 